\title{
The expected impact of the implementation of International Financial Reporting Standard (IFRS) 16 - Leases
}

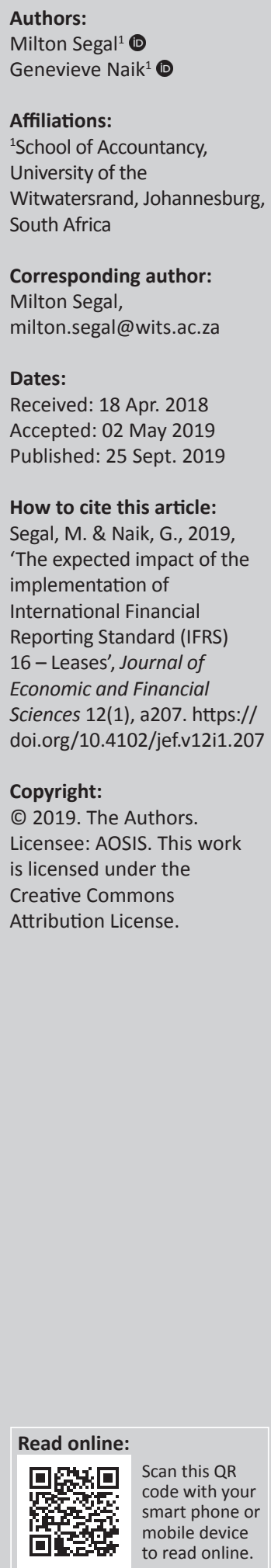

Orientation: The new standard on leases, International Financial Reporting Standard (IFRS) 16, will require the majority of lessees to account for lease arrangements on the face of the balance sheet. This is in contrast to the current standard and, as a result, the effects of this transition to on-balance sheet finance require analysis.

Research purpose: The purpose of this article is to identify and examine the material change implications that may arise from the implementation of IFRS 16 and determine its effect on both preparers and users of the financial statements with a specific focus on lessee accounting.

Motivation for the study: Leasing is a widely used economic transaction that affects the majority of corporates and individuals. There is a lack of formal academic literature surrounding the possible implications of the new accounting standard in a South African context.

Research approach, design and method: The authors performed a detailed literature review as well as gathered information at a public debate held jointly by the International Accounting Standards Board (IASB) and the South African Institute of Chartered Accountants (SAICA) to investigate what the implications may be.

Main findings: This article finds and concludes that there are potentially six change implications. The affected parties were identified as lenders, preparers and analysts with the banking and retail sectors requiring the most consideration.

Practical/managerial implications: Care will need to be taken when new lease transactions are entered into so that the entity still adheres to potential liquidity and solvency targets as well as loan covenant obligations.

Contribution/value-add: The normative and qualitative style sheds light on the effect of the imminent changes to South Africa's financial reporting structure, making an important contribution to financial reporting knowledge, transparency and accountability.

Keywords: IFRS 16; change implications; lease accounting; lessee; on-balance sheet; transparency.

\section{Introduction}

Leasing is an economic transaction that has been used since the early 1900s and forms one of the fundamental pillars of the related accounting transactions (Miller \& Upton 1976). It is also one of the most common finance-related decisions an entity will need to make (Ang \& Peterson 1984).

From a financial theory perspective, the concept of leasing makes economic sense (Werden 2005). When an entity requires the use of an asset or a resource to enhance an economic activity, it need not specifically purchase the asset outright but can rather gain the ability (or right) to use the asset for a particular period. This would be in exchange for compensating the asset's owner, most likely by way of payment. This can have potential working capital advantages too and serves as a mechanism for an entity potentially to manage its cash flows more efficiently (Grenadier 1996).

Since September 1982, lease accounting governed by International Accounting Standards (IAS) 17 requires both lessors (the legal owner of the asset) and the lessee (the party receiving the right to use the asset) to distinguish whether the lease is an operating or a finance lease (Branswijck, Longueville \& Everaert 2011; IAS 17 2001). 
This previous accounting standard, IAS 17, did not focus primarily on what an operating lease was, but rather defined an operating lease as a lease other than a finance lease. It was the failure to prove a finance lease that resulted in an operating one (Branswijck et al. 2011). This could be interpreted as an emphasis on what a finance lease is and, perhaps in terms of hierarchy, ranks it more highly than the operating lease.

While the difference in classification of finance versus operating leases was neither controversial nor ambiguous, the difference between the accounting of operating versus finance leases was both significant and material (Goodacre 2003). For an operating lease, no leased asset was required to be raised, and consequently no corresponding liability either (Baker \& Hayes 2004). This resulted in the accounting for operating leases being predominatly off the balance sheet.

With the implementation of International Financial Reporting Standard (IFRS) 16 - Leases, a significant change in the way leases are recognised, measured and disclosed has occurred. No longer will lessees be required to determine, with reference to the criteria in IAS 17 para 10, whether the lease meets the criteria of a finance lease, or not. Instead, IFRS 16 requires all leases to be accounted for, effectively, as finance leases from the lessee's perspective.

All lessees are now required to recognise a Right of Use (ROU) asset (IFRS 16, para 23), with a corresponding liability on their balance sheet (IFRS 16 para 26). These new assets and liabilities required may, and most likely will, imply a dramatic change to key ratios determined with reference to the amounts presented in the Annual Financial Statements (AFS) of lessees. IAS 1, Presentation of Financial Statements, requires a complete set of financial statements. This comprises a statement of financial position (SOFP), a statement of profit or loss and other comprehensive income (SOPLOCI), a statement of changes in equity (SOCIE) and a statement of cash flows. ${ }^{1}$

The purpose of this article is to examine the material change implications that may arise from the implementation of IFRS 16 and the effect they will have on the preparers and users of the financial statements with a specific focus on lessee accounting. This has been performed by conducting a literature review that synthesises the existing literature, similar to that as performed by Sylvester, Tate and Johnstone (2013), and provides a theoretical foundation to substantiate the presence of the research problem. This results, primarily, from the incoming requirement that all lessee accounting, with limited exceptions (see 4.6), be recorded on the balance sheet. The purpose of this research is not to provide a detailed review of the technical provisions of IFRS 16. Instead, this article deals with select principles from the new standard to provide a conceptual frame of reference for the material and significant findings.

1.For the purposes of this article, the SOFP is referred to as the balance sheet (B/S) and the SOPLOCI is referred to as the income statement $(\mathrm{I} / \mathrm{S})$. These are the historical names, and the names still referred to by users and analysts in practice.
This article makes a significant practical contribution by outlining six material change implications of the new standard that will require due consideration by the relevant parties. These are described by comparing IAS 17 to the IFRS 16 framework to ensure that the results are sufficiently detailed and resonate with practitioners, preparers and analysts. At the same time, the suggested implications and consequences raised in this article do not require advanced technical competence to interpret, thus increasing the likelihood of their application. At the theoretical level, the research adds to a limited body of literature on lease capitalisation ${ }^{2}$ in South Africa. It answers the call for more interpretive analysis of not only how but also why the amendments have been promulgated (Chambers, Dooley \& Finger 2015). Therefore, it makes an important qualitative contribution by using primary data received from users' comments on the preliminary drafts of the standard, from existing published literature and from the IASB itself to develop normative recommendations on how to apply and interpret the new standard (Maroun 2012). These should be relevant for both academics and practitioners.

This article does not fully examine the potential benefits of the new leasing standard, and does not provide a robust summary thereof, nor does it act as a comparative study between the possible advantages and disadvantages of the requirement for lessees to capitalise all leases. Furthermore, it does not provide a quantitative assessment of the costs and benefits of the IFRS 16 introduction in South Africa, but rather seeks to add to the existing debate on the implementation while informing users thereof. While this may be construed as a threat to validity and reliability in a positivist sense (Creswell 2009), the normative and qualitative style sheds light on what is and should be happening when it comes to South Africa's financial reporting structure, thus making an important contribution to financial reporting transparency and accountability (see Barth \& Schipper 2008; Dutzik, Imus \& Baxandall 2009). At the same time, the exploratory style provides a basis for subsequent research, which could rely on quantitative methods.

The remainder of this article is organised as follows: section 'An analysis of IAS 17' provides an in-depth analysis of IAS 17 and the effects thereof. Section 'The introduction of IFRS $16^{\prime}$ contains a review of the literature covering the new lessee accounting in terms of IFRS 16 and draws contrasts between it and IAS 17 in terms of disclosure, financial analysis and interpretations. Section 'Consequences of the move from off balance sheet to on balance sheet' examines the change implications of IFRS 16 and, in conjunction with supporting literature, determines its consequences for the affected stakeholders. Section 'Conclusion' concludes, identifies limitations of the research and provides areas for future research.

2.Capitalisation is a term referring to leases being disclosed on the face of the balance sheet by recognising a ROU asset and a corresponding liability, which balance sheet by recognising a ROU asset and a corresponding liability, which
equates to the future payment obligations in connection with obtaining the equates to the future
right to utilise the asset. 


\section{An analysis of IAS 17}

One of the fundamental focus areas of IAS 17 was the distinguishing characteristics of what constituted a finance lease (Beattie, Goodacre \& Thomson 2006). A finance lease is defined as a lease in which the significant risks and rewards of ownership pass from the lessor to the lessee (IAS 17 2001). Therefore, from an accounting perspective, the lessee would have recognised a leased asset as well as a corresponding liability on its balance sheet. Finance lease accounting has at times been referred to as accounting for the substance of the transaction, rather than its legal form (Baker \& Hayes 2004).

Paragraph 10 of IAS 17 goes into a significant amount of detail giving examples of what indicators suggest the existence of a finance lease. Such examples include transfer of ownership at the end of the lease, the degree of specialism of the asset, the length of the lease in comparison to the life of the asset and the present value of the contracted lease payments. The rationale is that if one cannot reasonably conclude that the lease transaction was a finance lease, it was, by a process of elimination, an operating lease.

While the distinguishing characteristics as described above are not inherently controversial, the difference in the accounting is both significant and material (Goodacre 2003). As a result, a certain amount of subjectivity existed, which led to a situation where two separate lessees could reach a different conclusion as to whether or not a finance lease existed (Beattie et al. 2006). This was because the lessees may have classified their lease arrangements differently based on their individual analysis of the lease classification indicators, which the standard allowed (Bauman \& Francis 2011).

Operating lease accounting is entirely dissimilar from that of a finance lease (Imhoff \& Thomas 1988). Because it was defined as a lease that is not a finance lease, the substance of the transaction is the antithesis of the above, and takes the form of a pure rental agreement only. No leased asset is raised, and consequently no corresponding liability either. Figure 1 illustrates these differences accordingly. The theory is quite simple: because no risks and rewards are deemed to pass to the lessee, no asset was deemed necessary to raise, and if no asset was raised, then no corresponding liability can be raised either (Imhoff, Lipe \& Wright 1991).

The operating lease disclosure the AFS contained was limited to the effect that the lease had on the income statement, either a lease rental expense from the lessee's perspective or a lease rental income from the lessor's (see Figure 1). The AFS did contain a note that listed the future cash flow commitments of the lessee categorised into periods within 12 months after financial year-end, between 1 and 5 years from financial yearend, and any period in excess of this. However, this note did not link to any specific asset or liability on the face of the balance sheet. Its purpose was to inform users of future cash flow implications of the lease agreement. An interesting update to IAS 17 transpired in 2005 where the IASB introduced a requirement to straight-line the lease income

\begin{tabular}{|c|c|}
\hline \multicolumn{2}{|c|}{$\begin{array}{l}\text { Scenario: } \\
\text { - Leased asset: machinery } \\
\text { - Lease term: } 3 \text { years } \\
\text { Lease payments: R10 } 000 \text { payable annually in arrears } \\
\text { Assume: } \\
\text { Lessee A classifies the lease as an operating lease under IAS } 17 \text { (Column 1) } \\
\text { Lessee A accounts for the lease under IFRS } 16 \text { (Column 2) }\end{array}$} \\
\hline IAS 17 (Column A) & IFRS 16 (Column B) \\
\hline $\begin{array}{l}\text { Lessee A: } \\
\text { Operating lease accounting }\end{array}$ & $\begin{array}{l}\text { Lessee } A \text { : } \\
\text { Lessee accounting }\end{array}$ \\
\hline $\begin{array}{l}\text { Balance sheet } \\
\text { (at inception of lease) } \\
\text { - Nil effect }\end{array}$ & $\begin{array}{l}\text { Balance sheet } \\
\text { (at inception of lease) } \\
\text { - Right of use asset: R } 24869 \dagger \\
\text { - Lease liability: (R24 869) }\end{array}$ \\
\hline $\begin{array}{l}\text { Income statement } \\
\text { (at inception of lease) } \\
\text { - Nil effect }\end{array}$ & $\begin{array}{l}\text { Income statement } \\
\text { (at inception of lease) } \\
\text { - Nil effect }\end{array}$ \\
\hline $\begin{array}{l}\text { Balance sheet } \\
\text { (at end of year } 1 \text { of lease) } \\
\text { - Nil effect }\end{array}$ & $\begin{array}{l}\text { Balance sheet } \\
\text { (at end of year } 1 \text { of lease) } \\
\text { - Right of use asset: R16 579٪ } \\
\text { - Lease liability: (R17 355)§ }\end{array}$ \\
\hline $\begin{array}{l}\text { Income statement } \\
\text { (at end of year } 1 \text { of lease) } \\
\text { - Rental expense: R10 000 }\end{array}$ & $\begin{array}{l}\text { Income statement } \\
\text { (at end of year } 1 \text { of lease) } \\
\text { - Depreciation expense: R8289+† } \\
\text { - Interest expense: R2487+\$ }\end{array}$ \\
\hline
\end{tabular}

Source: Adapted from Wits School of Accountancy notes - IFRS 16 - Leases

$\dagger$, The initial finance lease asset and liability is calculated as the present value of the annual lease payments using the effective interest rate.

$\$$. The finance lease asset is depreciated over the 3-year lease term. After 1 year of depreciation, the carrying amount is reduced to R16 579 .

$\S$, The finance lease liability is measured on an amortised cost basis. Interest at $10 \%$ is added to the initial liability and the payment of R10 000 is subtracted from the liability.

I, A lease or rental expense is recognised on a straight-line basis over the 3-year lease term. In this scenario, the annual lease payments are equal, so there is no need to straight-line the payments.

$\dagger$, Depreciation on the finance lease asset is calculated at R24 869/3 years.

\$. Interest on the finance lease liability is calculated at R15 $849 \times 10 \%$.

FIGURE 1: Illustration of lessee accounting under IAS 17 versus IFRS 16.

and lease expense in the case of an operating lease. This resulted in, effectively, an average lease income or lease expense being disclosed in the AFS (Mey 2016). Apart from this, operating lease accounting was off balance sheet.

As stated in the above paragraphs, under IAS 17, there was a distinct possibility that the AFS of two entities (lessees) with similar lease arrangements could look very different (Öztürk \& Serçemeli 2016). The lessee that classified its leases as operating leases (lessee A) would have no assets or liabilities associated with the leases on its balance sheet. Its income statement would disclose only the rental expense. That too would only be the straight-lined (average rental expense) and not represent an actual operating cash flow. On the contrary, the lessee that classified its leases as finance leases (lessee B) would have recognised lease assets and liabilities on its balance sheet. Its income statement would disclose (actual) depreciation of the leased asset and the interest expense on the loan. This interest would have been calculated by applying the effective interest rate implicit within the lease agreement, otherwise known as the incremental borrowing rate (IAS 17 2001). A practical illustration is provided in the Figure 1.

This figure illustrates that the only impact of the lease in the records of lessee $\mathrm{A}$ is the lease rental expense as opposed to that of lessee B, which discloses the effects of an asset controlled by the lessee and its corresponding liability. 
As noted in the preceding paragraphs, the balance sheet would not contain any mandatory disclosure notes apart from the note disclosure containing (operating) lease commitments. The purpose of this note was purely to inform users of the AFS about the extent of contractual cash payments the lessee had committed to in the future as a result of the signed lease agreement (Friedlob \& Plewa 2006; IAS 17 2001).

Significantly, this was merely a disclosure requirement; it did not form part of the liabilities presented on the face of the balance sheet as it looked at future cash outflows, not ones that had occurred in the reported financial year. As a result, the lease commitment note only provided additional information to the user, most useful for forecasting future operating commitments. A user was not able to tie in or link this note to an asset or liability on the face of the balance sheet (Van Greuning, Scott \& Terblanche 2011). Effectively, operating leases were accounted for off balance sheet.

\section{The introduction of IFRS 16}

The implementation of IFRS 16 will cause a material difference in the disclosure and presentation of the AFS for a significant number of lessees. This may impact the way users interpret the information produced by the AFS as compared to that under IAS 17 (Xu, Davidson \& Cheong 2017). An entity's financial ratios are determined with reference to the amounts published in its, generally externally audited, AFS. This is because the AFS provide a stable platform, have been prepared in accordance with IFRS and are what management of the entity faithfully represent as materially correct (Shamrock 2012). As a result, they represent a stable and meaningful comparison, allowing comparability across multiple industries and sectors (Emmanuel \& Garrod 2002). The change to the AFS and the numbers in the AFS will lead to a change in financial ratios.

Changes to lessee accounting will affect certain financial ratios of lessees. This is a concern to many lessees as various stakeholders use these ratios to measure an entity's performance, future prospects and even its creditworthiness (Altamuro et al. 2014). These ratios inform stakeholders, in making strategic decisions, regarding the operational and economic feasibility of the entity with a view to investing in or lending to the entity (Altamuro et al. 2014).

The IASB officially started its project to develop a new approach to lessee accounting as early as 2006. The IASB embarked on this project jointly with the Financial Accounting Standards Board (FASB). In addition, literature prior to 2006 exists where the impact of lessees classifying their leases as either operating or financing leases is analysed. Several studies have been conducted to evaluate the potential impact of including operating leases on the balance sheet by recognising an asset and a liability - similar to the approach under IFRS 16. In a study conducted in 2010 in the United States by Bryan, Lilien and Martin (2010), it was estimated that off balance sheet finance by the end of 2007 amounted to $\$ 1.26$ trillion on an undiscounted basis.
By comparison at that time, the amount of capital leases recognised on balance sheet amounted to approximately $\$ 110$ billion. The data confirmed that at the time and on a relative basis, operating leases had consistently been heavily preferred to capital leases.

They defined off balance sheet finance as lease transactions to which lessees were party to the asset and obligation thereon, but were, however, being recorded in the lessor's accounts. At this time, their study estimated that only $12 \%$ of all leases were accounted for on the SOFP, resulting in approximately $88 \%$ of all leases deemed operating and therefore off balance sheet (Bryan et al. 2010).

Seven years later, and with many corporates needing to stimulate business through investment, these percentages have further increased. These are material numbers clearly demonstrating the impact they will have on financial analysis using ratios (Bryan et al. 2010).

Smaller firms, measured in terms of net asset values, finance a significantly greater portion of their assets using operating leases (Kostolansky \& Stanko 2013). A focus of other studies (see Fülbier, Silva \& Pferdehirt 2008) has been on how large firms will be impacted by IFRS 16; however, Kostolansky and Stanko (2013) analysed the impact on smaller firms. Their study revealed that a significant increase in assets and liabilities would be experienced by these smaller firms. Their study concluded that $5 \%$ of their sample that represented over 200 entities will experience a 100\% increase in lease liability, while over half the total firms sampled (in excess of 2350 firms) would experience a 5\% increase in related liability. Their study thus concluded that the impact of lease capitalisation on their AFS would be significant and material (Kostolansky \& Stanko 2013).

Fülbier et al. (2008) concluded that the impact would be material, based on their selected companies, on the fashion and retail industry. However, the authors cautioned their regulator that the effects of operating lease capitalisation should not be overstated. This was driven by their conclusion that these industries generally had operating leases spanning shorter periods, and therefore limiting their overall exposure to significant accounting adjustments, as the lease contract would unwind relatively quickly. It would appear then that the authors were suggesting to users and the regulator to focus more on the longer term effects of lease capitalisation and not on the relatively significant, yet shorter lease terms (Fülbier et al. 2008).

In 2016, the IASB completed its process of changing the accounting for leases (You 2017). With the implementation of IFRS 16 - Leases, a significant change in the way leases are recognised, measured and disclosed has occurred. No longer will there be two methods of lessee accounting depending on whether the lease is classified as an operating or finance one. Instead, IFRS 16 requires all leases to be accounted for, effectively, as finance leases from the lessee's perspective. 
All lessees are now required to recognise a ROU asset (IFRS 16, para 23), with a corresponding liability on their balance sheet (IFRS 16 para26) initially measured as the present value of the future lease payments discounted at the rate applicable to the contract applying the effective interest rate method. The IASB has resultantly achieved its goal of migrating the majority of leases onto the balance sheet. There are only two circumstances where, per IFRS 16, a lessee will not be compelled to capitalise the ROU asset and corresponding liability as described above. These are (1) when the lease is a short-term lease with a 12-month (or less) duration or remaining duration, and (2) when the item being leased is considered an item of low value. Section 'Consequences of the move from off balance sheet to on balance sheet' expands on this discussion by illustrating the possible implications of this low-value exception.

Figure 1 illustrates the impact of IFRS 16 on lessee accounting and indicates the material impact of IFRS 16 on both the income statement and the balance sheet (Column B), whereas IAS 17 (Column A) had an almost nil impact other than the rental expense disclosure in the income statement.

\section{Consequences of the move from off balance sheet to on balance sheet}

Merton (1972) defined unintended consequences as 'outcomes that are not the ones foreseen and intended by a purposeful action'. At times, he also rephrased this theory as 'unanticipated or unforeseen consequences'. The term is generally construed in a negative way, implying that these unintended consequences cause an adverse effect, which departs from the original positive or proactive intention (Primavera 1999). Numerous studies have been performed that illustrate how legislation and changes that may be conceptually astute but not practical or commercially feasible to implement 'run the risk of producing unintended and potentially dysfunctional consequences' (see Segal 2017; Segal \& Maroun 2014; Vakkur, McAfee \& Kipperman 2010). The requirement by IFRS 16 for lessees to capitalise all leases can be seen as a departure from the previous standard, and the effects on the financial statements will require analysis. The intention of the standard has conceptual merit however, and does embody the spirit of the revised conceptual framework (Lessambo 2018). The new standard requires the asset, which is the economic resource to be capitalised, and the matching liability, which is the obligation to transfer an economic resource, to be presented in the financial statements. Because lease accounting was promulgated, operating lease arrangements have always given the lessee a right to use the underlying asset, which embodied economic benefits. In other words, operating leases have always created an asset for the lessee. Similarly, operating leases have always created a liability for the lessee as they impose a legal and contractual obligation on the lessee to make payments to the lessor over the lease term. Effectively then from a cash flow and economic perspective, lessees will be in the identical position before and after transitioning to IFRS 16.
Because of the materiality of the reported numbers now on the face of the financial statements, the implications and possible consequences, both potentially positive and negative, may be significant. This article suggests that the implications of the new leasing standard will need to be interrogated to determine the broader effect of its implementation.

This article explores the possible implications of the introduction of IFRS 16. A literature review of the existing body of literature on the introduction of lease capitalisation is carried out. The literature used is sourced predominantly from Europe and Australasia where similar changes to lease accounting are in the process of being promulgated. This has been used with a view to identify key change implications and any resultant consequences thereof. The implications raised have then also been applied to a South African context to formulate key implications that are expected to have the most material impact.

Before the release of the new standard, many organisations and professionals responded to the IASB's call for comments on the proposed standard at that time. The IASB received over 600 comment letters in response to the lease exposure draft (ED) published in May 2013 (Biondi et al. 2011). This clearly depicts the level of interest expressed by the affected communities (Biondi et al. 2011). Following the release of IFRS 16, the IASB itself released a document entitled 'Effects Analysis, IFRS 16 Leases'. In this document, the IASB describes the likely costs and benefits of IFRS 16, including the effect on key financial statement amounts and ratios of lessees (IASB 2016a). This document was as a direct result of the high number of comment letters received (IASB 2016a).

An ED is a pre-release of an intended new standard that the IASB releases. The purpose of this is to obtain feedback, both negative and positive, from potential users, including preparers, lenders, analysts, academics and auditors prior to the standard being formally accepted and promulgated. The ED preceded IFRS 16 and set out the IASB's proposed changes to lease accounting. Although the final lease accounting standard is, in some ways, dissimilar from what the IASB proposed in the ED, the fundamental principle of lessees recognising leases on balance sheet remains unchanged (SAICA 2016).

The consolidated summary compiled by the IASB containing the comment letters in relation to the EDs was analysed and grouped into themes based on the nature of the comment and the points raised. Similar points of concern, that is, points that were repeatedly raised by a number of respondents or implications raised, were used to identify the main themes. These were then categorised into who raised the concern and at whom the concern was aimed, that is, the affected parties. The main affected parties, as identified and expanded on in sections 'Costs versus benefits' through 'The effect of the change implications on lenders and analysts' below, were identified as lenders, preparers and analysts. The two most prominent sectors that were identified based on the volume 
of comments were the banking and retail sectors. It should be noted that not all comments received were negative. The document, however, is often used as a platform for users to express their opinion, which tends to dissent or differ from those of the IASB (Baudot, Demek \& Huang 2018).

\section{Costs versus benefits}

One of the concerns raised in response to the ED is that of cost versus benefit (Ernst \& Young 2013; SAICA 2013). Approximately $15 \%$ of respondents questioned whether the perceived benefits of the new lease accounting will really exceed the costs of implementing it (IASB \& FASB 2013). This is because of lessees having to incur significant costs when they transition from the old accounting standard, IAS 17, to the new accounting standard (Ernst \& Young 2013).

To capitalise existing operating leases on to their balance sheets, the authors suggest that lessees will need to analyse the terms of each lease contract. This will require lessees to gather and organise all existing lease contracts which could prove challenging where the contracts are not in an electronic form - hard copies may have been lost or misplaced over time. Copies of these documents would need to be acquired to then calculate the remaining lease liability and ROU. For large international companies, hard copies may also be held in different locations around the world. It may also require an upgrade of existing IT systems and training thereon (Bryan et al. 2010). Prior to this and in the absence of the physical documents, lessees could, potentially, have simply carried forward the straight-lined lease rental from prior periods and updated the lease commitment schedule accordingly. These costs are further discussed under section 'Implications on the banking sector' below.

\section{Implications on the banking sector}

One of the sectors that had reservations regarding the ED was the banking sector. Their main concern was the potential impact the new lease accounting would have on the stringent regulatory requirements of banks (IASB 2016b; SAICA 2013). Given the significance of the role of banking in South Africa, any consequences to the banks' AFS, whether intended or unintended, are seen to be significant (Bonin, Hasan \& Wachtel 2005)

Banks, because of the fiduciary nature of their business, are heavily regulated (Levine 2004; Fischel, Rosenfield \& Stillman 1987). A key service that banks offer is the safekeeping of customers' money. When a bank accepts a deposit from a customer, in a sense, the bank then owes that money to its customer and is reflected as a debtor in its customer's records and as a liability in the bank's records (Hughes 2004). This is because the customers can usually withdraw all or part of the cash deposited at any time, subject to the terms of the deposit or bank account held.

However, a bank holds a unique relationship with its customer as compared with a usual debtor and creditor relationship. Once a bank receives a cash deposit from its client, the money becomes the sole property of the bank. The bank gains the right to use the money as it sees fit without having an obligation to notify the investor or customer as to how the funds are allocated or how the funds will be used within the bank (Hughes 2004). Furthermore, the bank is not required to provide any type of surety or guarantee as a regular trade debtor (outside of a bank) may be required to do. For this reason, with banks having its client's funds to invest as it deems appropriate, banks and the banking industry as a whole are heavily regulated (Blum \& Hellwig 1995).

From a South African regulatory perspective, banks are required to comply with the Third Basel Accord (Basel III) to strengthen the regulation, supervision and risk management of the banking sector (Kasekende, Bagyenda \& Brownbridge 2012). Basel III prescribes both capital and liquidity requirements on banks aimed at improving a bank's ability to absorb both financial and economic stress [Bank of International Settlements (BIS) 2017b]. One such requirement is a liquidity coverage ratio. This ratio requires the bank to have sufficient spread of high-quality liquid assets to withstand a 30-day stressed funding scenario (BIS 2017a). This test purports to simulate the ability of the bank to withstand a run on the bank. This is a scenario where more than a certain percentage of customers decides to recall their funds invested in the bank (Diamond \& Dybvig 1983).

From a practical perspective and especially in a South African context, it is common these days for banks to be situated in convenient and safer locations such as shopping malls. In the majority of cases, the mall is not owned by the bank and the bank rents the space from the property owner. The arrangement with the landlord then qualifies as a lease. Under IAS 17, in almost all cases, the lease would be accounted for as an operating lease and so off balance sheet.

However, in terms of IFRS 16, where a bank is a lessee, although it will recognise both an asset and liability in respect of the lease on its balance sheet, the impact on the liquidity coverage ratio is significantly volatile (BIS 2017b). Because ROU assets will be long-term in nature and do not represent cash, they are expected to be categorised under Basel III as other assets as opposed to liquid assets (BIS 2017b).

The corresponding lease liabilities will increase the bank's total liabilities, resulting in a reserving requirement ${ }^{3}$ of $2.5 \%$ of the balance, as well as a liquid asset requirement of $5 \%$ of the balance (SAICA 2013). This would be as a result of the bank now being required to account for its obligation to settle its lease liability (IFRS 16). To this end, while the bank, accounting for its leases in terms of IFRS 16, would have no higher expected cash outflows than it would have under IAS 17 , the requirement to now recognise the debt on balance

3.T... reserve requirement (or cash reserve ratio) is a central bank regulation . The reserve requirement (or cash reserve ratio) is a central bank regulation employed by most of the world's central banks that sets the minimum amount of reserves (cash) that must be held by a commercial bank. The higher the liability, the higher the reserve requirement required by the bank. 
sheet by inference requires the bank to maintain more available cash on hand. It can also be noted that on the day the lease is entered into, the ROU asset will equal the lease liability. Subsequently, however, the ROU asset will be depreciated and thus decrease, while the liability will grow by the amount of interest accrued and will only decrease by the amount of principle repaid. It is therefore probable that the lease liability will exceed the ROU asset for the majority of the lease contract. The above places additional pressure on the bank's solvency ratio, as well as on the Basel III ratios (Berger et al. 2008). It is doubtful that this was the intention of the standard, but nevertheless, the result is a significant unintended consequence. To this end, the European Financial Reporting Advisory Group (EFRAG) responded that the effect should be modest in scale, as compared to assets under management, 'and would not in isolation represent a threat to the overall viability of the industry'. As mentioned in the preceding paragraphs above, it is the impression of the authors that this ramification will be enhanced in a South African context.

\section{Implications of changes to key financial ratios resulting from IFRS 16}

Changes to lessee accounting will affect certain financial ratios of lessees. This is a concern to many lessees as various stakeholders use financial ratios to measure an entity's performance, future prospects and even its creditworthiness (Altamuro et al. 2014). These ratios inform stakeholders in making strategic decisions by analysing the solvency, liquidity and operational effectiveness of the entity (Altamuro et al. 2014).

An additional sector, for which the effect of the new standard is purported to be significant, is that of the retail sector. Grossman and Grossman (2010) performed a study using 90 US-listed entities to measure the effect of lease capitalisation. Their findings differed among different industries. The three highest percentage increases in current liabilities were Gap (49.5\%), Rite Aid (45.6\%) and McDonald's (41.2\%). These represent three major retail industry outlets each having a significant effect on the financial analysis (Grossman \& Grossman 2010). The study focused on current liabilities as a mechanism of identifying debt that would now be raised on balance sheet requiring almost immediate settlement. It is the authors' assumption that this method was used as a mechanism of highlighting the short-term impact of lease capitalisation.

Goodacre (2003) conducted a study of 102 UK retail companies. It is common practice for retail companies to enter into property lease arrangements for their retail outlets. This is typically because retailers do not have the finance available to buy each and every property in which their outlets are situated. Under the accounting standards adopted by the 102 companies at the time, the majority of their property leases were classified as operating leases: no related assets or liabilities were recognised on their balance sheets for the leased properties. The study applied the constructive capitalisation method (CC method) (Goodacre 2003) to estimate the effect of recognising assets and liabilities on balance sheet for all property leases classified as operating leases. This method is used (e.g. by analysts) to capitalise off balance sheet debt, such as operating leases, onto the balance sheet. The CC method (Imhoff et al. 1991; Imhoff, Lipe \& Wright 1997) consists of incorporating in the balance sheet the present value of the discounted future payments derived from operating lease contracts. After applying the CC method, the study provides evidence of a significant impact on key financial ratios, including gearing, profit margin, return on assets (ROA), return on equity (ROE), interest coverage and asset turnover ratios (Rai \& Sigrin 2013). These ratios are key in financial decision-making (Nuryani, Heng \& Juliesta 2015). This impact, however, need not be construed in a negative light. Coupled to this new disclosure are also tax risks and tax consequences which ought to be adjusted for within the entity's own risk assessment model (Segal, Segal \& Maroun 2017). This article serves to make users aware of what the impact on the ratios as a result of lease capitalisation may entail.

Chambers et al. (2015) analysed the potential impact of the accounting proposed in the ED on the financial ratios of lessees. They found that the initial recognition of leased assets and liabilities on the balance sheet will also increase debt ratios, Earnings before Interest Tax and Depreciation (EBITDA) and interest expense while decreasing net income. The article goes on to discuss how the change in such ratios can have a ripple effect on stakeholders such as lenders, as a result of higher debt on balance sheet that may lead to a perceived higher credit (Chambers et al. 2015). The change in ratios may also affect employees if their employer has incorporated financial statement-based numbers (e.g. EBITDA or ROA) into employee incentive contracts. As changes in lease accounting could affect these reported numbers, companies without access to operating lease information may not be able to predict the effect of the changes on employee incentive-based compensation.

Following the release of IFRS 16, the IASB itself released a document entitled 'Effects Analysis, IFRS 16 Leases'. In this document, the IASB describes the likely costs and benefits of IFRS 16, including the effect on key financial statement amounts and ratios of lessees (IASB 2016b). The IASB has collectively referred to the costs and benefits of IFRS 16 as the effects of IFRS 16. It separates the costs into two main categories: implementation costs and ongoing costs. Implementation costs consist of the costs of new systems, acquiring and compiling existing information, costs of remeasurement and revaluations, and the training of the new standard to its employees. The IASB does not specify what the ongoing costs entail, but rather states that these should not be significantly higher than those that would have been incurred by the entity under IAS 17.

The IASB specifically mentions that it has gained insight on the likely effects through its consultation with various stakeholders throughout the project on leases. As a result of 
having to produce a complete effect analysis for the implementation of the new standard, this article puts forward the view that the full impact and potential ramifications of the new lease accounting standard were, perhaps, not fully known, nor completely understood, at the commencement of the project in 2006 (IASB 2016b).

It can be noted that the changes shown in Figure 2 are, to an extent, speculative as the standard is in its infancy and has not yet been tested practically because entities have not yet produced a set of AFS under IFRS 16. The changes expected by the IASB include those summarised in Figure 2.

Various stakeholders use financial ratios to assist in their decision-making (Lewellen 2004). This article supports the view that lessees are concerned about the impact the new accounting standard will have on their reported financial statements amount and resulting ratios. The following section explores how the decisions of lenders and analysts may be impacted.

\section{The effect of the change implications on lenders and analysts}

Lenders, such as banks, expose themselves to risk when they lend money to customers. A significant risk is credit risk, which is the risk that a customer may not be able to repay the loan (IASB 2016b:Appendix A) and that the lender may lose the principal of the loan or the interest associated with it (Waemustafa \& Sukri 2015). Credit risk arises because customers expect to use future cash flows to pay current debts. The generation of future cash flows, however, cannot be guaranteed, generating the term risk (Waemustafa \& Sukri 2015). It is a virtual impossibility to ensure that customers will have the future funds to repay their debts. Lenders charge customers interest on the principal amount of the loan, not only as compensation for the time value of money, but also as compensation for the credit risk assumed (Altamuro et al. 2014).

Interest income represents the income that lenders earn on loans issued (Altamuro et al. 2014). To this end, lenders, like any other entities operating a business for profit, seek to maximise the income they earn from issuing loans (Smith, Staikouras \& Wood 2003). Accordingly, they will charge a customer a higher interest rate if they believe the customer exposes them to a higher credit risk. Similarly, a customer with a lower credit risk will be charged a lower interest rate (Smith et al. 2003).

Because of the above, the assessment of credit risk is a critical part of a lender's business model (Grenadier 1996). In the situation where a credit rating agency has already published a credit rating for a customer, the lender can use this as a reference for credit risk. Where a credit rating is not publicly available for a customer, which is very often the case (Altamuro et al. 2014), the lender often assesses credit risk by analysing the audited AFS of the customer. The lender scrutinises the nature and amounts of the entity's assets, liabilities, income and expenses. It also computes and analyses various financial ratios as part of its analysis, for example the leverage ratio. If the lender does decide to lend, it will determine the interest rate that appropriately manages the entity's exposure to credit risk (Altamuro et al. 2014),

If a lender concentrated solely on the balance sheet and income statement of a lessee under IAS 17 operating leases as compared to the lessee using IFRS 16 (see Figure 1), the

\begin{tabular}{|c|c|c|c|}
\hline A & B & C & D \\
\hline Financial ratio & What it measures & Common method of calculation & Expected effect of IFRS 16 \\
\hline Leverage & Solvency & Liabilities divided by Equity & Increase \\
\hline \multicolumn{4}{|c|}{$\begin{array}{l}\text { Liabilities will increase because of the recognition of additional lease liabilities. Generally, there will be no initial impact on equity because while the lease liabilities cause } \\
\text { equity to decrease, the lease assets will cause equity to increase. }\end{array}$} \\
\hline Asset turnover & Profitability & Sales divided by Assets & Decrease \\
\hline \multicolumn{4}{|c|}{ Sales (or revenue) will not be impacted. Assets will increase because of the recognition of lease assets. } \\
\hline Interest expense & The interest incurred on a financial liability & Not applicable & Increase \\
\hline \multicolumn{4}{|c|}{$\begin{array}{l}\text { The additional lease liabilities will give rise to an increased interest expense. The lease liabilities will be measured using the amortised cost basis of accounting, which take } \\
\text { the time value of money into account. The initial lease liability will increase over the lease term with interest and decrease as lease payments are made by the lessee. }\end{array}$} \\
\hline Depreciation expense & $\begin{array}{l}\text { The depletion of an asset's remaining } \\
\text { useful life }\end{array}$ & Not applicable & Increase \\
\hline \multicolumn{4}{|c|}{$\begin{array}{l}\text { The additional ROU assets will give rise to an increased depreciation expense. The ROU assets will be treated in the same manner as owned assets in that they will be } \\
\text { consumed or depreciated as they are used. The consumption of the economic benefits embodied in the ROU assets will be recognised within depreciation expense. }\end{array}$} \\
\hline Rental expense & $\begin{array}{l}\text { The expense incurred in obtaining a right } \\
\text { to use an asset for a period of time }\end{array}$ & Not applicable & Decrease \\
\hline \multicolumn{4}{|c|}{$\begin{array}{l}\text { Rental expense will no longer be recognised in respect of most long-term leases. Instead, lessees will recognise interest expense on the lease liabilities and depreciation } \\
\text { on the ROU assets }\end{array}$} \\
\hline EBITDA $\dagger$ & Profitability & Refer name & Increase \\
\hline \multicolumn{4}{|c|}{$\begin{array}{l}\text { Under the old IAS } 17 \text { lease accounting, this ratio would have been determined taking rental expense for all operating leases into account. This means the EBITDA would } \\
\text { have been reduced by the rental expense recognised. Under the new IFRS } 16 \text { accounting, this ratio will increase because no rental expenses will be recognised } \\
\text { for long-term leases. }\end{array}$} \\
\hline EBITDAR & Profitability & Refer name & No change \\
\hline
\end{tabular}

Source: Adapted from Wits School of Accountancy notes: IFRS 16 - Leases

ROU, right of use.

†Earnings before interest, tax, depreciation and amortisation.

\$Earnings before interest, tax, depreciation, amortisation and rental expense.

FIGURE 2: Changes to financial amounts and ratios. 
lender could conclude that lessee A had a more favourable leverage ratio. With no lease liabilities on balance sheet and no interest expense in the income statement, the lender may assess the credit risk of lessee A to be lower than that of lessee B. This is despite the fact that the two lessees had the same lease payment commitments. This school of thought contributed to the structuring of lease arrangements by lessees to keep the leased assets and the corresponding liabilities off balance sheet (Grenadier 1996).

The elimination of operating lease accounting has many lessees concerned about a negative impact on their financial statement amounts and ratios (IASB \& FASB 2013). There is a concern that when lessees are required to apply IFRS 16 and capitalise their previous operating leases on balance sheet for the first time, lenders will see them in a different light. If lenders assess these lessees to be less credit worthy, they may be less inclined to provide new loans (Waemustafa \& Sukri 2015). They may also impose a higher interest rate on existing or future debt.

The authors suggest that this concern is valid. Lenders whose primary focus is on the financial statements would generally not consider an entity's off balance sheet debt when assessing credit risk. Previously, where the lease liabilities were not recognised on balance sheet, lessees were only required to disclose the total future lease payments they were committed to paying in a note to the AFS (IAS 17 2001:para 35). However, the other side of that debate suggests then that perhaps under IAS 17, with the majority of lessee's debt being off balance sheet, lessees were extended access to lease transactions based on better gearing, but they may not have been able to meet these lease payment obligations.

\section{The implications of the low-value exception}

In certain instances, and in terms of paragraph 5 of the IFRS 16 , a lessee may elect not to recognise a ROU asset and lease liability for its leases. This exemption from the general requirements of IFRS 16 can be elected for:

- short-term leases (i.e. where the lease term is 12 months or less)

- leases for which the underlying asset is of low value when it is new.

The second exemption is commonly referred to as the lowvalue exemption. It is this second criterion that requires the entity to use its discretion. This is because IFRS 16 does not provide a threshold or amount for determining whether an asset has a low value. KPMG in their guide to financial statements suggested an amount of $\$ 5000$ as an amount that ought to be considered low value (KPMG IFRG Limited 2016). If applied to a South African context, issues such as the foreign exchange rate may further complicate that threshold. The standard provides examples of low-value assets, including a tablet, personal computer, telephone or a small item of furniture (IFRS 16). In practice, lessees will need to apply their judgement (IFRS 16 2016a) about whether they believe an asset is of a low value or not. Importantly, however, the IASB expects all lessees, regardless of their size, nature or circumstances, to reach the same conclusion regarding whether an item is low value or not (IFRS 16 2016a). Based on this, a large listed company and small private company should reach the same conclusion. As a result, it seems that entities should not consider their own materiality levels when making their assessment (IASB 2016b:Appendix B, para 4).

The low-value exemption intends to capture leases that are high in volume but low in value. Furthermore, the IASB describes this as an assessment of costs versus benefits that applies to leases which, in the opinion of the preparer, are immaterial in relation to the AFS and therefore these leases need not comply with the IFRS 16 capitalisation requirements. The application of the exemption may mean that an entity that leases multiple low-value items may avoid the recognition of the related lease liabilities, even though, in aggregate, the liability would be material (KPMG IFRG Limited 2016). While this exemption may come as a relief to some lessees, one of the IASB's own members disagreed with the inclusion of this exemption in the new standard (IASB 2016c:Dissenting Opinion, para 1-9).

When IFRS 16 was published, it included a section entitled 'Dissenting Opinion' which explained why Mr Wei-Gui Zhang, an IASB board member, voted against the publication of IFRS 16 (IASB 2016c:Dissenting Opinion, para 1-9). Dissenting opinions demonstrate the transparency of 'due process' by ensuring that all views have been considered. They improve arguments on existing standards because the basis of conclusion must consider dissenting arguments and strengthen the counter arguments.

There were 14 board members at the time within the IASB. Mr Zhang did not believe that leases of low-value items should be treated differently from any other leases. He argued that if a lessee need not consider its own materiality levels when electing the exemption, a lessee could have many leased assets off balance sheet, even if, in aggregate, the leased assets have a high value. The AFS of such a lessee will not be comparable to those of a lessee with leases of highvalue assets, even if both lessees have similar future obligations for lease payments (IASB 2016c:Dissenting Opinion, para 1-9).

For example, if lessee 1 entered into a 5-year lease agreement for a vehicle with a fair value of R1 000000 , it would require lease capitalisation as per IFRS 16 . Compare this to lessee 2 who also entered into a 5-year lease agreement, but rather for 1000 desks costing R1000 each. Lessee 2 considered the leased item to be a low-value item, applied the low-value exemption and recognised neither a ROU asset, nor its corresponding liability. The result is IAS 17 operating lease type accounting for lessee 2 and virtually no impact or change to the reporting by adopting IFRS 16. Mr Zhang also noted that the low-value exemption could create the same tension 
between leasing and buying low-value assets, which existed when applying the requirements of IAS 17. He was concerned that entities that require material amounts of low-value assets could be incentivised to lease those assets rather than buy them to achieve off balance sheet accounting (IASB 2016c:Dissenting Opinion, para 1-9).

\section{The response to the change implications from the IASB}

The IASB's overarching response to these concerns (IASB $2016 \mathrm{~b}$ ) is that IFRS 16 represents a change only to the accounting. According to the IASB, IFRS 16 will provide more transparent information about a company's existing financial commitments, but it will not change those commitments. In other words, the company is still the same company (IASB 2016b) and so is still in the same financial position after the implementation of IFRS 16 as it was when it applied IAS 17. This is despite the potential for the balance sheet to be materially different. In addition, information received by the IASB indicates that most sophisticated users of financial statements (including credit rating agencies and lenders) already estimate the effect of off balance sheet leases on financial leverage, particularly when a company has a significant number of off balance sheet operating leases (IASB 2016b). Altamuro et al. (2014) suggest that lenders set interest rates based in part on credit ratings when published credit ratings are available. Lenders tend to adjust for off balance sheet leases obtained from IAS 17's lease commitment notes. Furthermore, the interest rates charged on loans granted to credit-rated borrowers are not expected to change because of the implementation of IFRS 16. If so, an argument can be raised that, perhaps, the disclosure of an operating lease under IAS 17 could have rather been upgraded to assist the analysts, rather than the implementation of an entire new standard.

\section{Conclusion}

The IASB had a clear goal - for lease assets and liabilities to be recognised on the balance sheets of lessees - but the additional consequences have become clearer over the project period. The Effects Analysis of the IASB notes that for leases previously classified as operating leases, the IASB expects significant changes in some financial ratios (IASB 2016b). This has been discussed by one IASB member, Darrel Scott, at the SAICA Panel Discussion held in August 2016 (SAICA 2016).

The adoption of IFRS 16 will in the near future cause the AFS of almost all lessees to look substantially different compared to the previous IAS 17 disclosure. Former operating leases will be capitalised, resulting in the presentation of 'new' assets and liabilities on the face of the balance sheet (Refer to Figure 2). The findings of this study suggest, however, that these assets and liabilities are not 'new' at all, but do require analysis by lenders, analysts and other users to understand the reasons for the change to the results reported on the face of the AFS.
The article analyses the significant differences between IFRS 16 and IAS 17 from a disclosure perspective and illustrated these by way of a tabular format. The previous literature surrounding the move to lease capitalisation described the material effect that the new standard's implementation may have on the lessee. These included not only disclosure changes, but also wider ramifications such as the effect on solvency ratios. This may impact the creditworthiness of lessees based on the additional debt that would now be presented on the face of the entity's balance sheet. By conducting a detailed literature review and examining the IASB's own literature and guidance on the standard, this article identifies a series of factors that would require consideration and analysis as a result of the transition to the new standard.

Firstly, there may be fairly significant costs involved in the implementation of the new standard that would not have been incurred had the standard not changed. These range from new systems, to costs incurred in gathering the required historical information for recalculation purposes. To some lessees, this may represent a cost of compliance that, depending on the amount, may exceed the benefit gained. To this end, the article also notes possible benefits of the compliance, such as a more representative balance sheet.

Secondly, the article noted a possible ramification to the banking industry that requires consideration. The requirement for banks to bring additional debt onto its own balance sheet may require the bank to obtain and retain additional reserves to comply with the highly regulated banking industry and its mandatory treaties.

The article identifies and describes the possible implications to the retail sector, which traditionally had a significant number of operating leases, and thus illustrating how bringing the lease debt on balance sheet could have a material impact to its financial statement ratios. The article then explores in detail the effect that the standard may have on lenders, users and indeed employees of the entity.

The article explores the potential impact of circumstances such as the low-value exception where lessees may be able to avoid compliance with the revised IFRS 16. Lastly, the article examines the IASB's own response to the implementation of the new standard that provides insight into their thought process and their intended consequences and enhancements to reporting for lease transactions.

The article concludes that a mature and informed user, once they become more informed and aware of the new standard, should be able to reach a similar conclusion in the analysis of a lessee's AFS, before and after the IFRS 16 application. Indeed, perhaps the initial panic over the implementation was a trigger reaction to change.

In reaching this conclusion, it should be noted that this study is not without limitations. It concentrates in an exploratory fashion only on the implementation of IFRS 16 
in a South African context to inform the ongoing debate. Future research needs to expand on this by examining advantages and disadvantages of lease capitalisations in other jurisdictions. In addition, this article has not carried out a detailed empirical analysis. Given the lack of formal literature on lease accounting in South Africa, a qualitative study was best suited to offering initial insights. Subsequent work may expand on this in a positivist setting, for example by simulating a model to quantitatively determine the amount of both debt and lease assets to be capitalised with a retrospective application.

\section{Acknowledgements}

The authors would like to acknowledge and thank Prof. Warren Maroun for his expert opinion and advice, and Mr Wayne van Zijl for his proofreading.

This article is based on the paper of the authors presented at the 2017 Southern African Accounting Association Biennial International Conference, titled: 'IFRS 16 LEASES - A significant change for lessees or "much ado about nothing"?' by Genevieve Naik and Milton Segal, available here:

http:/ / www.saaa.org.za/Downloads / 2017\%20Southern\% 20African $\% 20$ Accounting\%20Association $\% 20$ Conference $\%$ 20Proceedings.pdf from page 562.

\section{Competing interests}

The authors declare that they have no financial or personal relationships that may have inappropriately influenced them in writing this article.

\section{Authors' contributions}

M.S. and G.N. equally contributed to the idea, literature review and write-up of the article.

\section{Ethical considerations}

This article was written in the capacity of staff of the University of the Witwatersrand as part of the staff members' contribution to research. No human interviews were conducted and thus it poses no ethical concerns. Protocol number H15/09/34.

\section{Funding}

This research received no specific grant from any funding agency in the public, commercial or not-for-profit sectors.

\section{Data availability statement}

Data sharing is not applicable to this article as no new data were created or analysed in this study.

\section{Disclaimer}

The views expressed in this article are those of the authors and not an official position of the institution.

\section{References}

Altamuro, J., Johnston, R., Pandit, S.S. \& Zhang, H.H., 2014, 'Operating leases and credit assessments', Contemporary Accounting Research 31, 551-580. https://doi org/10.1111/1911-3846.12033

Ang, J. \& Peterson, P.P., 1984, 'The leasing puzzle', The Journal of Finance 39, 1055-1065. https://doi.org/10.1111/j.1540-6261.1984.tb03892.x

Baker, C.R. \& Hayes, R., 2004, 'Reflecting form over substance: The case of Enron Corp', Critical Perspectives on Accounting 15, 767-785. https://doi.org/10.1016/j. cpa.2002.08.001

Bank of International Settlements (BIS), 2017a, Basel III: International regulatory framework for banks, viewed 06 March 2017, from http://www.bis.org/bcbs/ basel3.htm.

Bank of International Settlements (BIS), 2017b. Basel III: The liquidity coverage ratio and liquidity risk monitoring tools, viewed 06 March 2017, from http://www.bis. org/publ/bcbs238.pdf.

Barth, M.E. \& Schipper, K., 2008, 'Financial reporting transparency', Journal of Accounting, Auditing \& Finance 23, 173-190. https://doi.org/10.1177/ $0148558 \times 0802300203$

Baudot, L., Demek, K.C. \& Huang, Z., 2018, 'The accounting profession's engagement with accounting standards: Conceptualizing accounting complexity through Big 4 comment letters', Auditing: A Journal of Practice and Theory 12, 87-103. https:// doi.org/10.2308/ajpt-51898

Bauman, M.P. \& Francis, R.N., 2011, 'Issues in lessor accounting: The forgotten half of lease accounting', Accounting Horizons 25, 247-266. https://doi.org/10.2308/ acch-10021

Beattie, V., Goodacre, A. \& Thomson, S.J, 2006, 'International lease-accounting reform and economic consequences: The views of UK users and preparers', The International Journal of Accounting 41, 75-103. https://doi.org/10.1016/j. international Journal

Berger, A.N., DeYoung, R., Flannery, M.J., Lee, D. \& Öztekin, Ö., 2008, ‘How do large banking organizations manage their capital ratios?', Journal of Financial Services Research 34, 123-149. https://doi.org/10.1007/s10693-008-0044-5

Biondi, Y., Bloomfield, R.J., Glover, J.C., Jamal, K., Ohlson, J.A., Penman, S.H. et al., 2011, A perspective on the joint IASB/FASB exposure draft on accounting for leases: American Accounting Association's Financial Accounting Standards Committee (AAA FASC)', Accounting Horizons 25, 861-871. https://doi.org/10. 2308/acch-50048

Blum, J. \& Hellwig, M., 1995, 'The macroeconomic implications of capital adequacy requirements for banks', European Economic Review 39, 739-749. https://doi. org/10.1016/0014-2921(94)00081-A

Bonin, J.P., Hasan, I. \& Wachtel, P., 2005, 'Bank performance, efficiency and ownership in transition countries', Journal of Banking \& Finance 29, 31-53. https://doi. org/10.1016/j.jbankfin.2004.06.015

Branswijck, D., Longueville, S. \& Everaert, P., 2011, 'The financial impact of the proposed amendments to IAS 17: Evidence from Belgium and The Netherlands', Accounting and Management Information Systems 10, 275.

Bryan, S.H., Lilien, S. \& Martin, D.R., 2010, 'The financial statement effects of capitalizing operating leases', The CPA Journal 80, 36.

Chambers, D., Dooley, J. \& Finger, C.A., 2015, 'Preparing for the looming changes in lease accounting', The CPA Journal 85, 38.

Creswell, J., 2009, Research design: Qualitative, quantitative, and mixed methods approaches, Sage, London, Thousand Oaks, CA.

Diamond, D.W. \& Dybvig, P.H., 1983, 'Bank runs, deposit insurance, and liquidity' Journal of Political Economy 91, 401-419. https://doi.org/10.1086/261155

Dutzik, T., Imus, B. \& Baxandall, P., 2009, Privatization and the public interest: The need for transparency and accountability in Chicago's public asset lease deals, Illinois PIRG Education Fund, Chicago, IL.

Ernst \& Young, 2013, Invitation to comment - Exposure draft leases, viewed 16 August 2016, from https://www.ey.com/za/en/issues/ifrs/issues gl ifrs nav exposuredrafts-and-comment-letters.

Emmanuel, C.R. \& Garrod, N., 2002, 'On the relevance and comparability of segmental data', Abacus 38, 215-234. https://doi.org/10.1111/1467-6281.00106

Fischel, D.R., Rosenfield, A.M. \& Stillman, R.S., 1987, 'The regulation of banks and bank holding companies', Virginia Law Review 12, 301-338. https://doi.org/10. 2307/1073067

Friedlob, G.T. \& Plewa, F.J. Jr., 1996, Understanding return on investment, John Wiley \& Sons, New York.

Fülbier, R.U., Silva, J.L. \& Pferdehirt, M.H., 2008, 'Impact of lease capitalization on financial ratios of listed German companies', Schmalenbach Business Review 60 122-144. https://doi.org/10.1007/BF03396762

Goodacre, A., 2003, 'Operating lease finance in the UK retail sector', The International Review of Retail, Distribution and Consumer Research 13, 99-125. https://doi. org/10.1080/0959396032000065373

Grenadier, S.R., 1996, 'Leasing and credit risk', Journal of Financial Economics 42 , 333-364. https://doi.org/10.1016/0304-405X(96)00882-3

Grossman, A.M. \& Grossman, S.D., 2010, 'Capitalizing lease payments', The CPA Journal 80, 6 .

Hughes, G., 2004, 'Deposit system and method of taking deposits', U.S. Patent Application 10/417, 159.

IAS 17, Leases, 2001, International Accounting Standards Board (IASB), IFRS Foundation, London. 
IASB, 2016a, IFRS 16, leases (2016), International Accounting Standards Board (IASB), London.

IASB, 2016b, IFRS 16, effects analysis, leases (2016), International Accounting Standards Board (IASB), London.

IASB \& FASB, 2013, Summary of Feedback on the 2013 ED, IFRS Foundation, London.

Imhoff, E.A. \& Thomas, J.K., 1988, 'Economic consequences of accounting standards: The lease disclosure rule change', Journal of Accounting and Economics 10 277-310. https://doi.org/10.1016/0165-4101(88)90006-7

Imhoff, E.A., Jr., Lipe, R.C. \& Wright, D.W., 1991, 'Operating leases: Impact of constructive capitalization', Accounting Horizons 5, 51.

Imhoff, E.A., Jr., Lipe, R.C. \& Wright, D.W., 1997, 'Operating leases: Income effects of constructive capitalization', Accounting Horizons 11, 12

Kasekende, L., Bagyenda, J. \& Brownbridge, M., 2012, Basel III and the global reform of financial regulation: How should Africa respond? A bank regulator's perspective, Bank of Uganda, Mimeo.

Kostolansky, J. \& Stanko, B., 2013, 'Cross-sectional analysis of operating lease liabilities by industry and firm size', Academy of Accounting and Financial Studies Journal $17,41$.

KPMG IFRG Limited, 2016, First impressions: IFRS 16 leases, viewed 17 April 2016, from https://home.kpmg/content/dam/kpmg/pdf/2016/01/leases-new-standard2016-01-14.pdf.

Lessambo, F.I., 2018, IFRS and GAAP. Financial Statements, Springer, Palgrave Macmillan, Cham.

Levine, R., 2004, The corporate governance of banks: A concise discussion of concepts and evidence, World Bank, Prague, Czech Republic.

Lewellen, J., 2004, 'Predicting returns with financial ratios', Journal of Financia Economics 74, 209-235., Switzerland. https://doi.org/10.1016/j.jfineco.2002. 11.002

Maroun, W., 2012, 'SOX - A comparison with the South African status Quo', Journal of Modern Accounting and Auditing 8, 357-364.

Merton, R.K., 1972, 'Insiders and outsiders: A chapter in the sociology of knowledge', American Journal of Sociology 78(1), 9-47.

Mey, M.T., 2016, 'The value relevance of straight-lining lease expenses', The International Business \& Economics Research Journal (Online) 15, 301. https://doi. org/10.19030/iber.v15i6.9830

Miller, M.H. \& Upton, C.W., 1976, 'Leasing, buying, and the cost of capital services', The Journal of Finance 31, 761-786. https://doi.org/10.1111/j.1540-6261.1976. tb01922.x

Nuryani, N., Heng, T.T. \& Juliesta, N., 2015, 'Capitalization of operating lease and its impact on firm's financial ratios', Procedia-Social and Behavioral Sciences 211 268-276. https://doi.org/10.1016/j.sbspro.2015.11.034

Öztürk, M. \& Serçemeli, M., 2016, 'Impact of New Standard 'IFRS 16 Leases' on statement of financial position and key ratios: A case study on an Airline Company in Turkey', Business and Economics Research Journal 7, 143. https://doi. org/10.20409/berj.2016422344
Primavera, J., 1999, 'The unintended consequences of volunteerism: Positive outcomes for those who serve', Journal of Prevention \& Intervention in the Community 18, 125-140. https://doi.org/10.1300/J005v18n01_10

Rai, V. \& Sigrin, B., 2013, 'Diffusion of environmentally-friendly energy technologies: Buy versus lease differences in residential PV markets', Environmental Research Letters 8, 014022. https://doi.org/10.1088/1748-9326/8/1/014022

SAICA, 2013, South African Institute of Chartered Accountants, Submission on ED/2013/6 - Leases, viewed 19 August 2016, from https://www.thedti.gov.za/ business regulation/meetings/28August2013/Agenda_Paper10.pdf.

SAICA, 2016, South African Institute of Chartered Accountants, Discussion panel on IFRS 16 - Leases, viewed 19 August 2016, from https://www.saica.co.za/Technical/ FinancialReporting/TheNewLeasesStandard/tabid/3893/language/en-ZA/ Default.aspx.

Shamrock, S.E., 2012, IFRS and US GAAP: A comprehensive comparison, John Wiley \& Sons, Hobokon, NJ.

Segal, M., 2017, 'ISA 701: Key audit matters-an exploration of the rationale and possible unintended consequences in a South African', Journal of Economic and Financial Sciences 10, 376-391.

Segal, M. \& Maroun, W., 2014, 'The introduction of a gambling tax in South Africawhat are the odds on the implementation thereof?', Journal of Economic and Financial Sciences 7, 361-374.

Segal, T., Segal, M. \& Maroun, W., 2017, 'The perceived relevance of tax risk-management in a South African context', Meditari Accountancy Research 25(1), 82-94.

Smith, R. Staikouras, C. \& Wood, G., 2003, Non-Interest Income and Total Income Stability, Bank of England Working Paper No. 198, Cass Business School Research Paper, viewed n.d., from http://dx.doi.org/10.2139/ssrn.530687

Sylvester, A., Tate, M. \& Johnstone, D., 2013, 'Beyond synthesis: Re-presenting heterogeneous research literature', Behaviour \& Information Technology 32, 1199-1215. https://doi.org/10.1080/0144929X.2011.624633

Vakkur, N.V., McAfee, R.P. \& Kipperman, F., 2010, 'The unintended effects of the Sarbanes-Oxley Act of 2002', Research in Accounting Regulation 22, 18-28. https://doi.org/10.1016/j.racreg.2010.02.001

Van Greuning, H., Scott, D. \& Terblanche, S., 2011, International financial reporting standards: A practical guide, 6th edn., World Bank, viewed 17 January 2017 , from https://openknowledge.worldbank.org/handle/10986/2288. License: CC BY $3.0 \mathrm{IGO}$.

Waemustafa, W. \& Sukri, S., 2015, 'Bank specific and macroeconomics dynamic determinants of credit risk in Islamic banks and conventional banks', International Journal of Economics and Financial Issues 5(2), 476-481.

Werden, G.J., 2005, 'The no economic sense test for exclusionary conduct', The Journal of Corporation Law 31, 293.

Xu, W., Davidson, R.A. \& Cheong, C.S., 2017, 'Converting financial statements: Operating to capitalised leases', Pacific Accounting Review 29, 34-54. https://doi org/10.1108/PAR-01-2016-0003

You, J., 2017, The impact of IFRS 16 lease on financial statement of airline companies, Auckland University of Technology, Auckland. 